\title{
Communication \\ Does Protection Really Matter? A Case Study from Central European Oak Forests
}

\author{
Kamila Reczyńska ${ }^{1, *(1)}$ and Krzysztof Świerkosz ${ }^{2}$ (1) \\ 1 Department of Botany, Institute of Environmental Biology, University of Wrocław, Kanonia 6/8, \\ PL-50-328 Wrocław, Poland \\ 2 Museum of Natural History, University of Wrocław, Sienkiewicza 21, PL-50-335 Wroclaw, Poland; \\ krzysztof.swierkosz@uwr.edu.pl \\ * Correspondence: kamila.reczynska@uwr.edu.pl
}

Received: 2 December 2019; Accepted: 18 December 2019; Published: 20 December 2019

\begin{abstract}
In the face of a rapidly changing global environment, detailed research into the actual role of protected areas (PAs) in preventing the destruction of ecosystems and the loss of biodiversity became particularly important. Using 304 phytosociological relevés of oak forests from SW Poland, we monitored their state of preservation reflected by the share of synanthropes (Ws-c index) in relation to (i) duration of protection, (ii) status of protected area, (iii) main topographic factors, and (iv) bedrock type. We show that the Ws-c index of studied forests depends primarily on the habitat conditions, especially bedrock type, while both the duration and status of protection are not relevant. The most disturbed are forests developing on serpentine substrates regardless of whether they are protected or not. Within the rest of the investigated sites, the Ws-c index is significantly lower and does not meaningfully differ between protected and unprotected areas. On the one hand, our results suggest that the fact of establishing protection does not ensure a favourable state of conservation of forest communities. On the other hand, well-preserved forest communities can also be expected outside PAs what makes them an important target for nature protection in the future.
\end{abstract}

Keywords: conservation status; forest communities; monitoring; natura 2000 sites; nature reserves; neophytes; protected areas; synanthropes

\section{Introduction}

It is considered that protected areas (hereafter PAs) are of the particular importance of conservation biology due to their role in reducing the decline in biodiversity in various types of ecosystems and species extinction rates [1,2]. It is also assumed that they give an opportunity for constant provisioning of ecosystem services of high quality [3-6]. Therefore, it seems obvious that PAs have become one of the main tools used in nature conservation in the face of rapid changes in the global environment. By 2020, it is planned to increase the surface of protected terrestrial areas and inland water as well as coastal and marine areas up to $17 \%$ and $10 \%$, respectively [7]. However, the relations between the management of PAs and the effectiveness of protection reflected by the decline in loss of biodiversity have been still poorly recognized [8]. According to the recent studies, the number and surface of PAs worldwide appear to be insufficient for the protection of animal populations [8-11], just as they do not always reduce the destruction of habitats [12], despite the fact PAs are often established in places of very low economic potential [13]. On the other hand, it is assumed that the PAs network is efficient when it comes to the protection of forest communities, at least in terms of protecting their already existing area [8,14] and is positively correlated with the date of establishment of PA [15]. Therefore, we wondered whether the PAs network was also effective in protecting the quality of preserved communities expressed in the combination of native plant species, especially since the location within 
PA does not exclude other threats to biodiversity, e.g., invasion of alien species, including invasive neophytes [3,15-18].

For this purpose, we monitored the state of preservation of oak forests (both acidophilous and thermophilous) in three types of protected areas, from strictly protected natural reserves, through landscape parks to Natura 2000 (hereafter N2000) sites and unprotected forest complexes in SW Poland. The oak forests of this part of Poland are well-recognized in terms of species composition, ecological diversity and distribution $[19,20]$. Therefore, they can be a model object in monitoring research which enables to capture full of their variability in different aspects including a degree of their anthropogenic disturbance.

The main goals of this study were (i) to determine, to what extent PAs with a different date of establishment and status of protection contribute to a favourable state of conservation of studied forest communities. We expected that the older and more strictly protected the area, the forest communities are better preserved within it; (ii) to test which other factors the condition of studied forest communities depends on.

\section{Materials and Methods}

\subsection{Subject of Research}

The research was conducted within acidophilous and thermophilous oak forests (belonging to Quercion roboris and Quercion petraeae alliances, respectively) in the Sudetes and their foothills (SW Poland, Figure 1). These forest communities represent one of the most valuable elements of Central European vegetation marked by the unique plant species combination and richness. For instance, in thermophilous oak forests, more than 70 species on $200 \mathrm{~m}^{2}$ can be recorded [20]. Due to their high biotic values, they are protected as Natura 2000 habitats (9190 Old acidophilous oakwoods with Quercus robur on sandy plains and *91I0 Euro-Siberian steppic woods with Quercus spp.) under the European Union Habitats Directive [21].

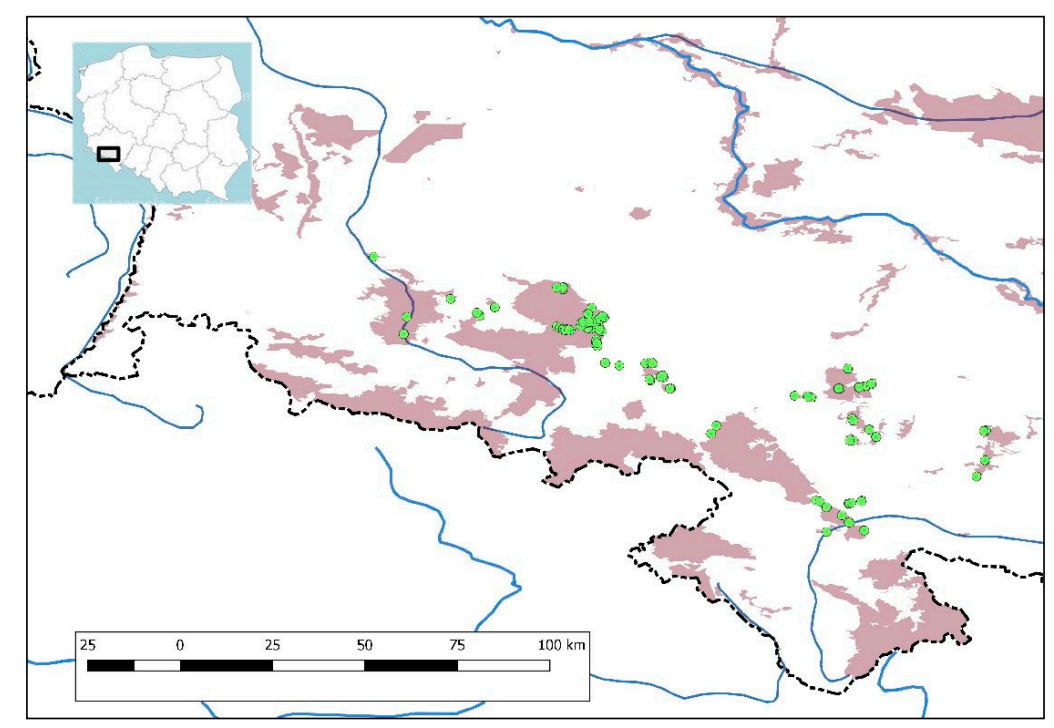

Figure 1. Distribution of oak forest relevés within the investigated area on the background of N2000 sites.

Oak forests were intensively managed from the Middle Ages to the mid-20th century, mostly as coppice, coppice-with-standards forests or wood pastures [22,23]. In the coppice system trees after cutting regenerate vegetatively growing shoots from the stool or the root system. It causes that the same tree can be cut several times (in a short rotation of 10-30 years) without losing its ability to grow new shoots [24]. This traditional type of management generated both socioeconomic and ecological benefits. The former related to the role of oakwoods as a source of firewood and tanbark $[24,25]$. 
The latter was reflected by the creation of very diversified habitat conditions on a relatively small area, which resulted in the simultaneous occurrence of species with different ecological requirements. This was mainly caused by specific light conditions which can be characterized as the shifting mosaic of light and dark phases, soil disturbance and nutrient uptake [22,26].

Due to long-term economic use, most of the studied communities are ancient forests, at the age exceeding 250 years. However, because the coppicing was still conducted in the early 20th century, the age of the stands ranges from 90 to 120 years currently. For this reason, oak forests of the studied area are usually found within larger forest complexes with an area from 1 to $100 \mathrm{sq}$. $\mathrm{km}$. Therefore, they rarely border open areas, which can be the source of anthropophytes.

Depending on their locality, they prefer warm and dry (or moderately mesic) habitats from steep, south-facing slopes with shallow, skeletal or sandy soils to loess plateaus. They do not occur on north-facing slopes, where they are replaced by oak-hornbeam forests.

\subsection{Data Collection}

We used 304 phytosociological relevés of studied communities which were collected according to the Braun-Blanquet approach [27] within forest communities with at least $80 \%$ of tree layer consisting of oak species [20]. The area of most relevés was $200 \mathrm{~m}^{2}$ and was adapted to those values proposed by Chytrý \& Otýpková [28] for forest communities. All the relevés are available via the Polish Vegetation Database [29].

Among topographic parameters, we used heat load index (HL), slope aspect and slope inclination. The basic data on topography was obtained from a numerical model of terrain (NMT). The HL index which shows direct solar radiation reaching the site during the year, taking into account latitude, slope, and exposure of the slope was calculated from the formula of McCune \& Keon [30]. The values of aspect were transformed along the N-S line, folding 0-360 to 0-180 such that NE $=\mathrm{NW}, \mathrm{SE}=\mathrm{SW}$, etc. The slope inclination was obtained from the NMT directly. Altitude was not included in further analyses due to strong correlation with the distribution of ultrabasic bedrocks $(\rho=0.37, p<0.001)$.

Based on the criterion of mineral composition such as content of quartz, potassium feldspars, plagioclase [31], rocks were classified into three categories: (i) acidic (e.g., granite, rhyolite, gneiss, sandstone, conglomerate and mudstone), (ii) basic (basalt, andesite, trachyte, amphibolite, spilite, greenstone and greenstone schist), and (iii) ultrabasic (serpentine).

The monitoring covered seven nature reserves, five landscape parks and 14 N2000 sites. These are all PAs of the studied area where oak forests occur. Therefore, the monitoring can be considered representative of the region. It should be also emphasized that the mentioned PAs are nested areas in character. The earliest established nature reserves of small surface are surrounded by landscape parks which in turn are the part of N2000 sites with an even larger area, constituting a buffer zone for the remaining, previously established PAs. Therefore, in cases when PAs with different protection status overlapped, we classified them into the highest protection status. Among all collected relevés 281 plots were located within at least one PA, whereas 23 plots $(7.6 \%)$ were outside any form of protection. Considering the date of creation, PAs were divided into three main periods. The first applies to the years 1957-1962, when the first three nature reserves were created (21 relevés), the second covering the years 1981-1992 falls on the period of creation of landscape parks (141 relevés), while the third covering the years 2000-2004 is the time of creation of N2000 ecological network and the rest of nature reserves (119 relevés).

\subsection{Data Analysis}

As an objective indicator of the disturbance of plant community, we used a Ws-c index which describes the percentage share of non-forest species-native and alien-in a single vegetation plot in relation to the total number of species [32]. The Ws-c index is used in the analysis of the degree 
of anthropogenic changes of the flora and plant communities in Europe e.g., [33,34], including forest communities [35]. The Ws-c index was calculated as follows:

$$
W s-c=\frac{A p+A}{S p+A} * 100 \%,
$$

where Ws-c - percentage share of synanthropes; Ap - number of native non-forest species in a single relevé; A-number of alien species in a single relevé; $\mathrm{Sp}$-number of native species in a single relevé

The list of anthropophytes and non-forest native species used to calculate the Ws-c index (Appendix A) was prepared based on Zając \& Zając [36], Mirek et al. [37], and Tokarska-Guzik et al. [38].

Since the output data did not match with the normal distribution, we used non-parametric methods-Spearman's rank correlation, Kruskal-Wallis test for equal medians with Dunn's post hoc test and Wilcoxon signed-rank test—all embedded in PAST 3.0 software [39].

\section{Results}

We found no correlation between the Ws-c index and both the duration and type of protection. Instead of that, the obtained results reveal that the percentage share of synanthropes is mainly connected with the type of bedrock and (weakly) with HL index (Table 1).

Table 1. Spearman's rank correlation of the Ws-c index (percentage share of synanthropes) with studied factors (duration and type of protection, bedrock type and topography).

\begin{tabular}{|c|c|}
\hline $\begin{array}{c}- \\
\text { Duration and Type of Protection }\end{array}$ & $\rho$ \\
\hline Duration of protection ( $0-58$ years) & $0.072^{\text {n.s. }}$ \\
\hline Nature Reserves & $0.060^{\text {n.s. }}$ \\
\hline N2000 sites & $0.004^{\text {n.s. }}$ \\
\hline Landscape Parks & $-0.102^{\text {n.s. }}$ \\
\hline Unprotected areas & $0.098^{\text {n.s. }}$ \\
\hline Bedrock & - \\
\hline Ultrabasic & $0.352 * * *$ \\
\hline Acidic & $-0.145^{*}$ \\
\hline Basic & -0.113 * \\
\hline Topography & - \\
\hline HL index & $-0.145 *$ \\
\hline Aspect & $0.017^{\text {n.s. }}$ \\
\hline Slope $\left[{ }^{\circ}\right]$ & $0.002^{\text {n.s. }}$ \\
\hline
\end{tabular}

Explanation: n.s. - not significant; ${ }^{*}-p<0.05 ;{ }^{* * *}-p<0.001 ; \rho$ (rho) - Spearman's rank correlation coefficient.

The Ws-c index significantly differs when we compare the type of protection or its lack combined with bedrock type (Kruskal-Wallis test $\mathrm{H}=28.53, p<0.001$,). The oak forests occurring on soils derived from ultrabasic (serpentine) rocks significantly stand out among studied communities (according to the results of Dunn's post hoc test). Irrespective of their location in the strictly protected nature reserves or unprotected areas with regular forest management - the mean value of the Ws-c index is $11.16 \%$ and $14.15 \%$, respectively), comparing to oak forests occurring on other types of substrate (mean Ws-c from $1.78 \%$ to $5.1 \%$ ) (Figure 2 ).

After excluding oak forests occurring on ultra-basic soils from the analysis, the remaining oak forests developing on other types of substrates did not show statistically significant differences in the percentage of synanthropes (Kruskal-Wallis test $\mathrm{H}=4.458, p=0.73$ ), regardless of what type of area (with various protection status or unprotected) they occur in. 


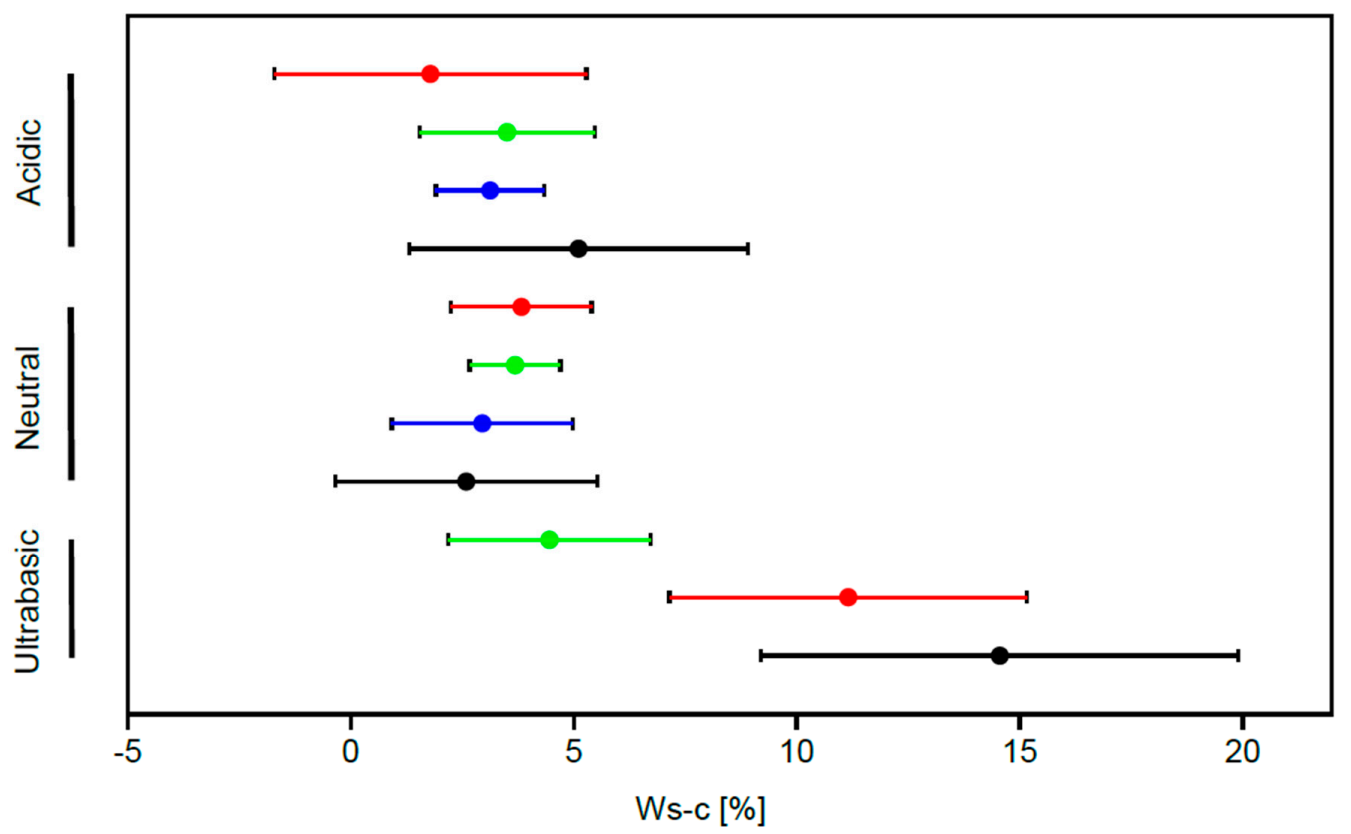

Figure 2. The mean values of the Ws-c index (percentage of synanthropes) and standard error showed as whisker. The length of the whiskers is one sigma. Black - unprotected areas, red - nature reserves, green - landscape parks, blue - N2000 sites.

The negative correlation of the Ws-c index with the HL index (Table 1; Figure 3) is weak but suggests that the share of synanthropes increases as the HL index decreases. In other words, oak forest communities which develop on the slopes with lower inclination and exposure more strongly deviated from SW direction are more disturbed and their Ws-c index achieves higher values.

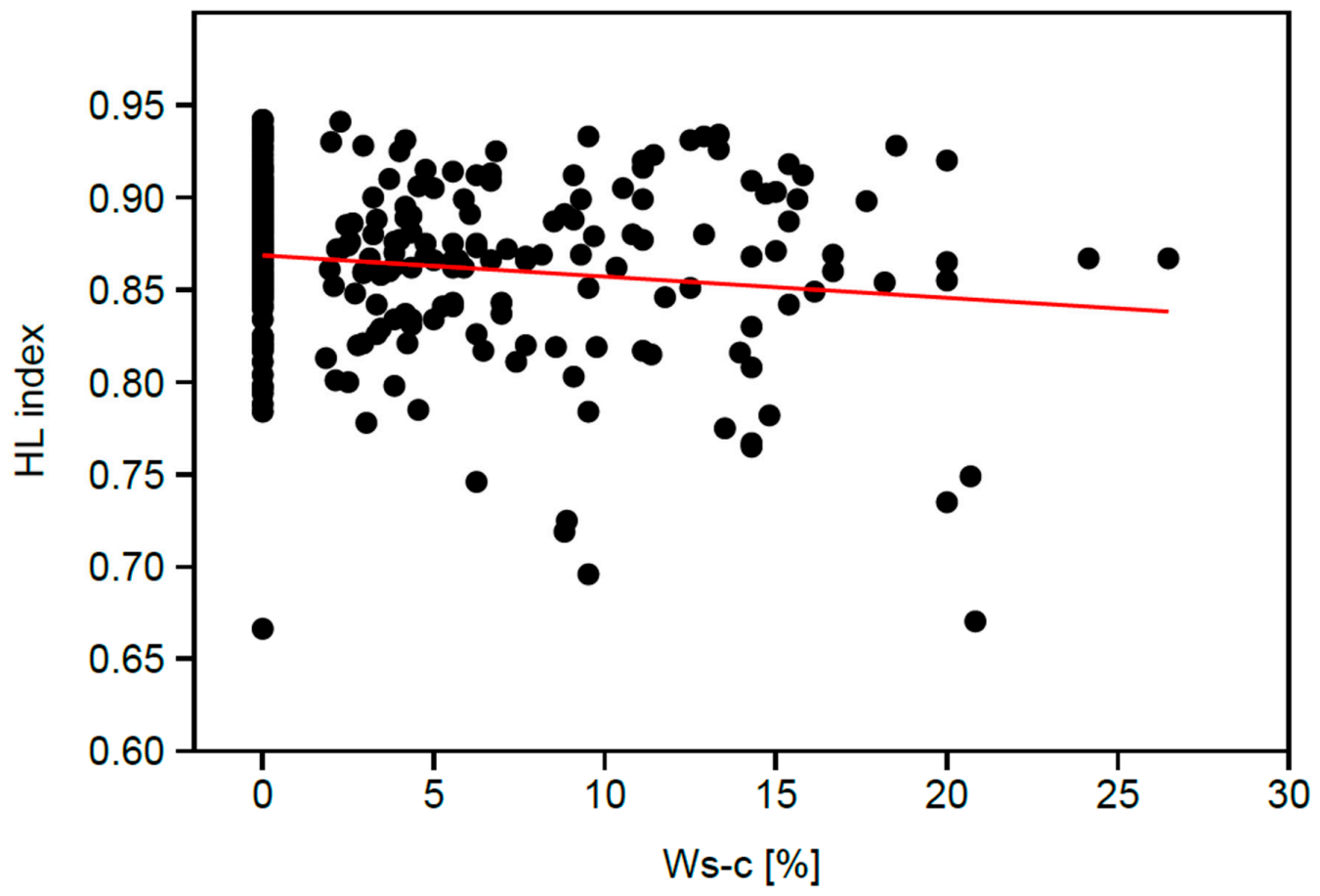

Figure 3. Spearman rank correlation coefficient of the heat load index (HL) with the Ws-c index (percentage share of synanthropes). Red line - linear bivariate model (slope 0.001, intercept 0.86). 


\section{Discussion}

The share of synanthropes in the studied oak forests depends primarily on the conditions of the habitat in which they occur, especially bedrock type, while both the length of the conservation period and the protection status (strict, landscape, habitat protection) are not relevant for their state of preservation. The obtained results are not isolated, but the analyses concerning the occurrence of synanthropes in forest communities within PAs are dispersed and demonstrated using different and as such difficult to compare methods. Kiedrzyński et al. [40] found an increase in the average coverage of synanthropic species in the Tomczyce reserve (Central Poland) from 5.1\% to $8.6 \%$ over 40 years. The flora anthropogenization rate in the Skarpa Wiślicka reserve (Southern Poland), reaches almost $6 \%$ [41]; in the swamp forests of the Żurawiniec nature reserve (Western Poland), 45 years after its creation the neophytization rate achieves 10.5\% [42]. In the fir forests of the Rudka Sanatorium reserve (Central Poland), the proportion of synanthropic species is 28.5\% [43], whereas in the herb-rich beech forests of the Cisy reserve (Southwestern Poland) it achieves 9\% [44].

However, the most important factor responsible for the changes in species composition seems to be invasion of neophytes. The issue of the rapid invasion of Impatiens parviflora into PAs of Central Europe was raised among others by Pyšek et al. [15], Obidziński \& Symonides [45], Chmura \& Sierka [46] and Łysik [47]. Impatiens parviflora is also often found in studied oak forests, constituting the most common of the listed neophytes. Moreover, according to Levine [48], ecosystems with the highest biodiversity may be the most vulnerable to invasion, and such are often protected in PAs. For instance, in the riparian forests in the Ojców National Park (Southern Poland) 42\% of vascular plant species are anthropophytes [49], whereas in the Białowieża Forest—-the last preserved lowland European forest with high degree of naturalness-they constitute $37 \%$ of the total number of plant species, even if they do not occur in the best preserved forest communities [50].

It, therefore, seems that PAs with a higher status of protection not always provide higher levels of biodiversity (understood as a high degree of naturalness of flora) as it was stated by Lecina-Diaz et al. [6]. Moreover, the results of Sallustio et al. [51], revealing that habitat quality depends on the intensity of the anthropogenic impacts and is sensitive to different protection levels are not confirmed in this study.

Of course, the proportion of synanthropes in forests subject to intensive anthropopressure may be even higher and vary (depending on the community and habitat conditions) between $49 \%$ and $60 \%$ [52], even if they are formally protected, e.g., due to their floristic values, like the Choczewskie Cisy reserve in Poland [44].

On the one hand, our results suggest that the fact of establishing protection does not ensure a favourable state of conservation of forest communities. On the other hand, well-preserved forests with a high degree of naturalness can also be expected outside PAs and hence they may become an important target for nature protection in the future $[6,10,53]$. It may also mean, that the current conservation status of forest communities assessed based on their cover, continuity in the landscape and role in provisioning ecosystem services, e.g., [4,5] should be treated with caution and may require an update, based on direct field research on their species composition. Despite putting great attention to invasion of neophytes [15-18], native non-forest invasive species may also change the character of forest communities and deteriorate their conservation status.

Although the HL index is correlated with both slope inclination and exposure (Wilcoxon test in both cases $p<0.001$ ), the Ws-c index does not depend on topographic variables obtained from direct field studies. This highlights the role of synthetic indicators in ecological research, because they may provide information on factors affecting the habitat (in this case, the intensity of penetration of synanthropes into forest communities) that are not noticeable without their help. However, this is still surprising that the proportion of geographically and ecologically alien species in studied communities weakly depends on topographic factors reflected by the HL index. 
Author Contributions: Conceptualization, methodology, validation, formal analysis, investigation, resources, K.R., K.Ś.; software, data curation, K.Ś.; writing—original draft preparation, K.R., K.Ś.; writing-review and editing, K.R., K.Ś.; visualization, K.Ś.; All authors have read and agreed to the published version of the manuscript.

Funding: This research received no external funding.

Conflicts of Interest: The authors declare no conflict of interest.

\section{Appendix A}

The list of species used in calculation of the Ws-c index (percentage share of synanthropes) 


\section{Neophytes}

- Amelanchier spicata

- Conyza canadensis

- Impatiens parviflora

- Padus serotina

- Pseudotsuga taxifolia

- Quercus rubra

- Robinia pseudacacia

\section{Archaeophytes}

- Fallopia convolvulus

- Solanum luteum

- Vicia hirsuta

- Viola arvensis

Species escaped cultivation (both native and alien)

- Cotoneaster horizontalis

- Malus domestica

- Sorbus intermedia

- Larix decidua

\section{Non-forest native species}

- Aegopodium podagraria

- Agropyron repens

- Alliaria petiolata

- Allium oleraceum

- Anthriscus sylvestris

- Arenaria serpyllifolia

- Calamagrostis epigejos

- Chaerophyllum aromaticum

- Chamaenerion angustifolium

- Dactylis glomerata

- Galeopsis tetrahit

- Galium aparine

- Geranium robertianum

- Geum urbanum

- Holcus lanatus

- Hypochoeris radicata

- Rubus caesius

- Sambucus nigra

- Sarothamnus scoparius

- Senecio jacobaea

- Taraxacum sect. Ruderalia

- Torilis japonica

- Urtica dioica

- Verbascum nigrum

- Vicia cracca. 


\section{References}

1. Soizic Le, S.; Michael, H.; Yichuan, S.; Adrian, H.; Cyril, B.; Thomas, M.B.; Bastian, B.; Stuart, H.M.B.; Simon, N.S.; Tim, B.; et al. Protected areas and effective biodiversity conservation. Science 2013, 80, $803-805$. [CrossRef]

2. David, V.; Zuzana, V.H.; Helena, K.; Kateřina, S. Human transformation of ecosystems: Comparing protected and unprotected areas with natural baselines. Ecol. Indic. 2016, 66, 321-328. [CrossRef]

3. Brooks, T.M.; Mittermeier, R.A.; Da Fonseca, G.A.B.; Gerlach, J.; Hoffmann, M.; Lamoreux, J.F.; Mittermeier, C.G.; Pilgrim, J.D.; Rodrigues, A.S.L. Global biodiversity conservation priorities. Science 2006, 80, 58-61. [CrossRef] [PubMed]

4. Castro, A.J.; Martín-López, B.; López, E.; Plieninger, T.; Alcaraz-Segura, D.; Vaughn, C.C.; Cabello, J. Do protected areas networks ensure the supply of ecosystem services? Spatial patterns of two nature reserve systems in semi-arid Spain. Appl. Geogr. 2015, 60,1-9. [CrossRef]

5. $\quad$ Eastwood, A.; Brooker, R.; Irvine, R.J.; Artz, R.R.E.; Norton, L.R.; Bullock, J.M.; Ross, L.; Fielding, D.; Ramsay, S.; Roberts, J.; et al. Does nature conservation enhance ecosystem services delivery? Ecosyst. Serv. 2016, 17, 152-162. [CrossRef]

6. Lecina-Diaz, J.; Alvarez, A.; De Cáceres, M.; Herrando, S.; Vayreda, J.; Retana, J. Are protected areas preserving ecosystem services and biodiversity? Insights from Mediterranean forests and shrublands. Landscape Ecol. 2019, 34, 2307-2321. [CrossRef]

7. Convention on Biological Diversity. Available online: https://www.cbd.int/sp/targets/ (accessed on 20 November 2019).

8. Geldmann, J.; Barnes, M.; Coad, L.; Craigie, I.D.; Hockings, M.; Burgess, N.D. Effectiveness of terrestrial protected areas in reducing habitat loss and population declines. Biol. Conserv. 2013, 161, 230-238. [CrossRef]

9. Wiersma, Y.F.; Nudds, T.D. Efficiency and effectiveness in representative reserve design in Canada: The contribution of existing protected areas. Biol. Conserv. 2009, 142, 1639-1646. [CrossRef]

10. García-Bañuelos, P.; Rovito, S.M.; Pineda, E. Representation of Threatened Biodiversity in Protected Areas and Identification of Complementary Areas for Their Conservation: Plethodontid Salamanders in Mexico. Trop. Conserv. Sci. 2019, 12, 1940082919834156. [CrossRef]

11. Bosso, L.; Ancillotto, L.; Smeraldo, S.; D'Arco, S.; Migliozzi, A.; Conti, P.; Russo, D. Loss of potential bat habitat following a severe wildfire: A model-based rapid assessment. Int. J. Wildland Fire 2018, 27, 756-769. [CrossRef]

12. Clark, N.E.; Boakes, E.H.; McGowan, P.J.K.; Mace, G.M.; Fuller, R.A. Protected areas in South Asia have not prevented habitat loss: A study using historical models of land-use change. PLoS ONE 2013, 8, 1-7. [CrossRef] [PubMed]

13. Joppa, L.N.; Pfaff, A. High and far: Biases in the location of protected areas. PLoS ONE 2009, 4, e8273. [CrossRef] [PubMed]

14. Rodríguez, N.; Armenteras, D.; Retana, J. Effectiveness of protected areas in the Colombian Andes: Deforestation, fire and land-use changes. Reg. Environ. Change 2013, 13, 423-435. [CrossRef]

15. Pyšek, P.; Jarošík, V.; Kučera, T. Inclusion of native and alien species in temperate nature reserves: A historical study from Central Europe. Conserv. Biol. 2003, 17, 1414-1424. [CrossRef]

16. Pyšek, P.; Jarošík, V.; Kučera, T. Patterns of invasion in temperate nature reserves. Biol. Conserv. 2002, 104, 13-24. [CrossRef]

17. Lambdon, P.W.; Pyšek, P.; Basnou, C.; Hejda, M.; Arianoutsou, M.; Essl, F.; Jarošík, V.; Pergl, J.; Winter, M.; Anastasiu, P.; et al. Alien flora of Europe: Species diversity, temporal trends, geographical patterns and research needs. Preslia 2008, 80, 101-149.

18. Plant Invasions in Protected Areas; Foxcroft, L.C.; Pyšek, P.; Richardson, D.M.; Genovesi, P. (Eds.) Springer: Dordrecht, The Netherlands; Heidelberg, Germany; New York, NY, USA; London, UK, 2014; p. 656. [CrossRef]

19. Reczyńska, K. Udział gatunków synantropijnych w zbiorowiskach z klasy Quercetea robori-petraeae Br.-Bl. et R.Tx. 1943 w Sudetach i na ich Przedgórzu. Acta Bot. Sil. 2011, 7, 113-123.

20. Reczyńska, K. Diversity and ecology of oak forests in SW Poland (Sudetes Mts). Phytocoenologia 2015, 45, 85-106. [CrossRef] 
21. Interpretation Manual of European Union Habitats-EUR28. Available online: https://ec. europa.eu/environment/nature/legislation/habitatsdirective/docs/Int_Manual_EU28.pdf (accessed on 16 December 2019).

22. Rackham, O. Woodlands; Collins: London, UK, 2006; p. 608.

23. Ellenberg, H. Vegetation Ecology of Central Europe; Cambridge University Press: New York, NY, USA, 2009; p. 756.

24. Szabó, P. Driving forces of stability and change in woodland structure: A case study from the Czech lowlands. Forest Ecol. Manag. 2010, 259, 650-656. [CrossRef]

25. Szymura, T.H. Tradycyjna gospodarka odroślowa w Europie Środkowej i jej wpływ na różnorodność biologiczna. Sylwan 2010, 154, 545-551.

26. Hédl, R.; Šipoš, J.; Chudomelová, M.; Utinek, D. Dynamics of herbaceous vegetation during four years of experimental coppice introduction. Folia Geobot. 2017, 52, 83-99. [CrossRef] [PubMed]

27. Mueller-Dombois, D.; Ellenberg, H. Aims and Methods of Vegetation Ecology; Reprint; The Blackburn Press: Caldwell, NJ, USA, 2002; p. 547.

28. Chytrý, M.; Otýpková, Z. Plot sizes used for phytosociological sampling of European vegetation. J. Veg. Sci. 2003, 14, 563-570. [CrossRef]

29. Kącki, Z.; Śliwiński, M. The Polish Vegetation Database: Structure, resources and development. Acta Soc. Bot. Pol. 2012, 81, 75-79. [CrossRef]

30. McCune, B.; Keon, D. Equations for potential annual direct incident radiation and heat load. J. Veg. Sci. 2002, 13, 603-606. [CrossRef]

31. Bolewski, A.; Parachoniak, W. Petrografia, 3rd ed.; Wydawnictwa Geologiczne: Warszawa, Poland, 1988; p. 656.

32. Jackowiak, B. Anthropogenic changes in the flora of vascular plants of Poznań. Wyd Nauk UAM Ser. Biol 1990, 42, 1-234.

33. Sudnik-Wójcikowska, B. Synantropization indices of urban floras: An attempt at definition and assessment. Acta Soc. Bot. Pol. 1991, 60, 163-185. [CrossRef]

34. Chmiel, J. Flora of vascular plants of the eastern part of the Gniezno Lake District and its anthropogenic transformations in the 19th and 20th centuries, part 1. Prace Zakładu Taksonomii Roślin UAM w Poznaniu 1993, 1, 1-202.

35. Falencka-Jabłońska, M. Species of synantropic plants as indicators of the transformation level of forest biocenosis. Studia i Materiały Centrum Edukacji Przyrodniczo-Leśnej 2007, 9, 279-287.

36. Zając, M.; Zając, A. A tentative list of segetal and ruderal apophyte in Poland. Zesz. Nauk. UJ. Pr. Bot. 1992, 24, 7-23.

37. Mirek, Z.; Piękoś-Mirkowa, H.; Zając, A.; Zając, M. Flowering Plants and Pteridophytes of Poland. A Checklist; W. Szafer Institute of Botany Polish Academy of Sciences: Kraków, Poland, 2002; p. 442.

38. Tokarska-Guzik, B.; Dajdok, Z.; Zając, M.; Zając, A.; Urbisz, A.; Danielewicz, W.; Hołdyński, C. Alien Plants in Poland with Particular Reference to Invasive Species; Generalna Dyrekcja Ochrony Środowiska: Warszawa, Poland, 2012; p. 197.

39. Hammer, Ø.; Harper, D.A.T.; Ryan, P.D. PAST: Paleontological statistics software package for education and data analysis. Palaeontol Electron. 2001, 4, 1-9.

40. Kiedrzyński, M.; Zielińska, K.; Grzelak, P. Transformation of forest vegetation after 40 years of protection in the Tomczyce Nature Reserve (Central Poland). Folia Biol. Oecologica 2011, 7, 207-227. [CrossRef]

41. Wilczek, Z.; Wika, S.; Gorczyca, M.; Bregin, M. Flora roślin naczyniowych rezerwatu przyrody Skarpa Wiślicka na Pogórzu Śląskim. Acta Bot. Silesiaca 2014, 10, 99-118.

42. Stachnowicz, W.; Rusińska, A.; Pawlik, A. Synanthropization of flora and vegetation of transitional peat bog remaining under human pressure-the "Żurawiniec" Nature Reserve in Poznań. Rocz nauk Pol Tow Ochr Przyr "Salamandra" 2003, 7, 27-63.

43. Piórek, K.; Krechowski, J. Synantropizacja flory rezerwatu jodłowego Rudka Sanatoryjna (woj. Mazowieckie). Chrońmy Przyrodę Ojczystą 2007, 63, 82-96.

44. Fałtynowicz, W.; Halama, M.; Kmiecik, M. Flora roślin naczyniowych rezerwatu "Cisy" koło Barda (południowo-zachodnia Polska). Acta Bot. Sil. 2004, 1, 35-48.

45. Obidziński, T.; Symonides, E. The influence of the groundlayer structure on the invasion of small balsam (Impatiens parviflora DC.) to natural and degraded forests. Acta Soc. Bot. Pol. 2000, 69, 1-8. [CrossRef] 
46. Chmura, D.; Sierka, E. The occurrence of invasive alien plant species in selected forest nature reserves in southern Poland as a conservation problem. Nat. Conserv. 2006, 62, 3-11.

47. Łysik, M. Ten years of change in ground-layer vegetation of European beech forest in the protected area (Ojców National Park, South Poland). Pol. J. Ecol. 2008, 56, 17-31.

48. Levine, J.M. Species Diversity and Biological Invasions: Relating Local Process to Community Pattern. Science 2000, 288, 852-864. [CrossRef]

49. Sołtys-Lelek, A.; Barabasz-Krasny, B.; Możdżeń, K. Synanthropization of riparian plant communities in the Ojców National Park (Southern Poland). Biodiv. Res. Conserv. 2016, 44, 35-53. [CrossRef]

50. Jaroszewicz, B.; Cholewińska, O.; Gutowski, J.J.; Samojlik, T.; Zimny, M.; Latałowa, M. Białowieża Forest-A Relic of the High Naturalness of European Forests. Forests 2019, 10, 849. [CrossRef]

51. Sallustio, L.; De Toni, A.; Strollo, A.; Di Febbraro, M.; Gissi, E.; Casella, L.; Geneletti, D.; Munafo, M.; Vizzarri, M.; Marchetti, M. Assessing habitat quality in relation to the spatial distribution of protected areas in Italy. J. Environ. Manag. 2017, 201, 129-137. [CrossRef] [PubMed]

52. Gawenda-Kempczyńska, D.; Paszek, I.; Załuski, T. Regeneration of vegetation in manor park in Laskowice (Dabrowa Forest District). Ecol. Quest. 2017, 27, 39-52. [CrossRef]

53. Cox, R.L.; Underwood, E.C. The importance of conserving biodiversity outside of protected areas in Mediterranean ecosystems. PLoS ONE 2011, 6, e14508. [CrossRef] [PubMed]

(C) 2019 by the authors. Licensee MDPI, Basel, Switzerland. This article is an open access article distributed under the terms and conditions of the Creative Commons Attribution (CC BY) license (http://creativecommons.org/licenses/by/4.0/). 